A RCHIWA, BIBLIOTEKI

I MUZEA KOŚCIELNE 112 (2019)

https://doi.org.10.31743/abmk.2019.112.13

TOMASZ NOWICKI* - LUBLIN

\title{
ŹRÓDLA DO BADAŃ PROZOPOGRAFICZNYCH NAD DUCHOWIEŃSTWEM I PERSONELEM PARAFIALNYM DIECEZJI WLOCŁAWSKIEJ W OKRESIE NOWOŻYTNYM
}

\begin{abstract}
Streszczenie
Źródła dotyczące nowożytnych parafii odnotowują grupy ludzi zarządzających i wspomagających działanie tych ośrodków. Byli to ministrii ecclesiae, czyli duchowieństwo i wspomagający ich personel pomocniczy, czyli służba kościelna. Ci pierwsi to ministri sacramentorum. Spełniali najistotniejszą rolę $\mathrm{w}$ parafii, choć w badanym okresie mogła ona wykraczała ona poza granice ścisłej obsługi religijnej i duszpasterskiej. Z kolei świeccy pełnili funkcje pomocnicze wspomagając duchowieństwo w różnorodnych zadaniach wykonywanych w parafii. Byli to zatem zakrystianie, nauczyciele, kantorzy, organiści, kalikanci, dzwonnicy, grabarze, ale też położne czy ministranci.

W artykule zostały przedstawione źródła, z których czerpać można wiedzę na temat wspomnianych wyżej grup. Zostało to ukazane na przykładzie materiałów archiwalnych dotyczących przedrozbiorowej diecezji włocławskiej. Do najciekawszych i najważniejszych źródeł, zawierających najwięcej informacji o ludziach zaangażowanych w życie parafii należą akta wizytacji kanonicznych. Nie są one całkowicie jednorodne. Nie zawsze obejmują wszystkie parafie diecezji, ale nade wszystko mają różny zakres informacyjny, bo tworzono je o różne kwestionariusze pytań. Niemniej te najpełniejsze informacyjnie są znakomitym źródłem do badań nad duchowieństwem parafialnym i służbą kościelną.

Do badań zwłaszcza nad duchowieństwem parafialnym przydatne są księgi wpisów powstałe w urzędach konsystorskich, ale także te pochodzące $z$ kancelarii biskupiej. W tym przypadku szczególną wartość poznawczą mają księgi biskupich czynności pontyfikalnych, zwłaszcza zaś księgi święceń duchownych. Wyjątkowym źródłem informacji do badań prozopograficznych, choć w perspektywie studiów nad duchowieństwem i służbą kościelną raczej o cha-
\end{abstract}

* Tomasz Nowicki - dr hab. historii; prof. w Instytucie Historii Katolickiego Uniwersytetu Lubelskiego Jana Pawła II; e-mail: tonowi@kul.pl

https://orcid.org/0000-0003-1185-9358 
rakterze pomocniczym, są księgi metrykalne. Kancelarie parafialne tworzyły je w miarę systematycznie począwszy od Soboru Trydenckiego. Dzięki temu możliwe jest uzyskanie dynamiki opisu, jeśli zachowana jest systematyczność i ciągłość tej dokumentacji.

Poza tym wiedzę o duchowieństwie i służbie parafialnej czerpać należy z wielu innych rodzajów źródeł: metryk kolegiów i seminariów, klasztornych ksiąg zmarłych, opisów kościołów i parafii sporządzanych przez różnych autorów, akt kapitulnych, pojawiających się pod koniec XVIII wieku schematyzmów diecezjalnych, ale także w aktach o proweniencji świeckiej, jak np. księgach z kancelarii miejskich.

Słowa kluczowe: prozopografia; duchowieństwo; słudzy kościelni; diecezja włocławska

Parafie Kościoła łacińskiego w przedrozbiorowej Polsce, poza funkcjami ściśle duszpasterskimi, spełniały także ważną rolę administracyjną. Były bowiem nie tylko najmniejszymi jednostkami w strukturach kościelnych, ale także wykonywały zadania charakterystyczne dla państwowej organizacji terytorialnej. $\mathrm{Na}$ te bardzo szerokie funkcje parafii zwracano już uwagę w literaturze przedmiotu. W czasach staropolskich zadania parafii nie sprowadzano tylko do posług religijnych (kult) czy moralno-wychowawczych (nauczanie prawd wiary i moralności katolickiej), ale także oświatowych (szkoły parafialne) i opiekuńczych (szpitale i przytułki parafialne). W nowożytnej parafii toczyło się życie religijno-towarzyskie (bractwa i stowarzyszenia religijne) ${ }^{1}$. W mikrośrodowiskach parafialnych najważniejszą rolę odgrywało duchowieństwo, przede wszystkim zaś rządcy parafii. To oni spełniali zadania przywódcze, nauczając i wychowując nie tylko w duchu ściśle religijnym, lecz także społecznym i obywatelskim. Role pomocnicze sprawowali wikariusze parafialni i inni księża mniej lub bardziej okazjonalnie pracujący w parafii ${ }^{2}$. Tę swoistą ,elitę” parafialną uzupełniali świeccy bardziej zaangażowani $\mathrm{w}$ działalność lokalnego ośrodka kościelnego. Zwykle była to aktywność wynikająca z pełnionych funkcji, stąd do tej kategorii osób zaliczyć wypada nauczycieli realizujących zadania edukacyjne w szkołach parafialnych, kantorów, potem coraz częściej organistów i kalikantów potrzebnych do realizacji oprawy muzycznej w czasie parafialnych nabożeństw. Personel pomocniczy stanowili też zakrystianie, dzwonnicy, a nawet grabarze. Specyficzną rolę odgrywały położne, który musiały być odpowiednio przygotowane do nadzwyczajnego udzielenia sakramentu chrztu, a tym samym zaakceptowane przez rządców parafii. W tym kontekście warto też wspomnieć o chłopcach usługujących kapłanom do mszy, których w szerszym kontekście, podobnie zresztą jak położne, można również zaliczyć do sług parafialnych ${ }^{3}$.

Warto zadać pytanie, skąd czerpać informacje o ludziach, którzy mieli większy lub mniejszy wpływ na znaczną część staropolskiego społeczeństwa. Źródła,

${ }^{1}$ Zob. S. Litak, Parafie w Rzeczypospolitej XVI-XVIII wieku, Lublin 2004, s. 10, 362 i n.; A. Jabłońska, Funkcje społeczne parafii archidiakonatu gnieźnieńskiego w XVII wieku, Kielce 2013, s.10-12.

${ }^{2}$ Tamże, s. 136 i n.

${ }^{3}$ Tamże, s. 168 i n. 
które mogą służyć do badań prozopograficznych nad duchowieństwem i służbą kościelną zostaną zaprezentowane $\mathrm{w}$ oparciu o materiały dotyczące diecezji włocławskiej. Na początku należy jeszcze zdefiniować, jak rozumieć termin $d u$ chowieństwo. Duchownym, w rozumieniu ówczesnego prawa, była osoba, która przyjęła tonsurę ${ }^{4}$. By ją uzyskać stawiano kandydatom odpowiednie wymagania, podobnie zresztą, jak kandydatom do kolejnych święceńs. Po otrzymaniu tonsury władze kościelne i państwowe traktowały daną osobę jako należącą do stanu duchownego i podlegała pod jurysdykcję sądową Kościoła. W artykule interesuje nas jednak tylko duchowieństwo parafialne, czyli ta część kleru, która podlegała jurysdykcji miejscowego ordynariusza i za jego zgodą sprawowała funkcje sakralne w kościołach parafialnych.

Z kolei termin stużba kościelna, czyli po prostu personel pomocniczy wykonujący różnorakie zadania dodatkowe i wspomagające działania duchownych parafialnych, służące realizacji różnorakich zadań spoczywających na parafii, do których nie były wymagane święcenia kapłańskie ${ }^{6}$. Zatem słudzy parafialni, to ludzie świeccy, choć czasami niektórzy słudzy kościelni mogli posiadać tonsurę lub niższe święcenia duchowne ${ }^{7}$.

W ogólniejszym rozumieniu obie te kategorie ludzi były określane niekiedy jako ministri Ecclesiae, czyli słudzy Kościoła. Co zrozumiałe, różniły się te dwie grupy dość wyraźnie. Duchowni to ministri sacramentorum, których należy odróżnić od „zwykłych” - świeckich sług kościelnych8.

Chcąc charakteryzować parafialne duchowieństwo przedrozbiorowe, należy na początku odróżnić z jednej strony rządców parafii, z drugiej parafialny kler pomocniczy. Wśród rządców jednak spotkamy takich, którzy mieli instytucję kanoniczną i z tego tytułu pełnoprawnie administrowali beneficjami parafialnymi. Ale do rządców można niekiedy zaliczać komendarzy, którzy tymczasowo kierowali daną parafią albo też czynili to w zastępstwie instytuowanego na beneficjum kapłana, który nie przebywał na terenie parafii. W tym drugim rozumieniu należałoby ich traktować raczej jako kler pomocniczy ${ }^{9}$. Co więcej, również wśród

${ }^{4}$ Zob. H. Rybczyński, Duchowieństwo, stan duchowny, w: Encyklopedia katolicka (dalej: EK), t. 4, red. R. Łukaszyk, Lublin 1983, kol. 307; tenże, Duchowny, EK, t. 4, red. R. Łukaszyk, Lublin 1983, kol. 309. Por. S. Olczak, Duchowieństwo parafialne diecezji poznańskiej w końcu XVI $i$ w pierwszej połowie XVII w., Lublin 1990, s. 7.

${ }^{5}$ Decretales summorum pontificum pro Regno Polonie et constitutiones synodorum provincialium et dioecesanarum Regni eiusdem ad summam collectae, ed. Z.Chodyński, E.Likowski, t. 1, Posnaniae 1883, s. 97-98.

${ }^{6}$ Zob. T. Nowicki, Ministri ecclesiae. Stużba kościelna $i$ witrycy $w$ diecezji włocławskiej w XVIII wieku, Lublin 2011, s. 7-8.

${ }^{7}$ Zob. Litak, Parafie w Rzeczypospolitej XVI-XVIII wieku, s. 168-169.

${ }^{8}$ Zob. Nowicki, Ministri ecclesiae, s. 62-64.

${ }^{9}$ Zapisy źródłowe nie odróżniają komendarzy zastępujących plebanów od plebanów, którzy administrują np. sąsiednią wakującą parafią per commendam. Często w obu przypadkach używa się nazwy commendarius. Podobnie autorzy opracowań naukowych zaliczają tę grupę duchowieństwa albo do kleru pomocniczego albo też do rządców parafii, ale bez samodzielności przypisanej instytuowanym prepozytom i plebanom. Por. S. Olczak, Zarządcy parafi diecezji poznańskiej w pierwszej połowie XVII wieku (w świetle wizytacji kanonicznych), „Roczniki Humanistyczne”, 30 (1982) 
duchowieństwa posiadającego instytucję kanoniczną można wyodrębnić jeszcze dwie kategorie kleru, a mianowicie prepozytów i plebanów. Różnica między nimi nie polegała w tym wypadku na uprawnieniach wobec parafian i praw do beneficjum, lecz wiązała się innym charakterem samego beneficjum parafialnego. Prepozyt, czyli proboszcz, to duchowny, który stał na czele prepozytury i kolegium mansjonarzy - jednostki kościelnej zorganizowanej na podobieństwo kapituł, ale w mniejszej, parafialnej skali. Podobnie jak kapituła, grupa duchownych na czele z prepozytem, powinna charakteryzować się wspólnotą życia i modlitwy (np. wspólnie odprawiając przepisane fundacją oficja). Taki kościół parafialny z prepozyturą tego typu zwano właśnie prepozyturalnym, a stojącego na jego czele plebana zwano prepozytem. Do takiego tytułu nie mieli prawa „zwykli” plebani, których w wizytacjach diecezji włocławskiej określano najczęściej terminami parochus, plebanus czy rector ecclesiae ${ }^{10}$. Oczywiście tytuł prepozyta był bardziej prestiżowy niż parocha czy plebana, stąd w późniejszym czasie przyjął się w spolszczonej wersji jako proboszcz na określenie wszystkich bez wyjątku rządców parafii. Termin ten zatem, w przypadku archidiakonatu pomorskiego, nie oznaczał duchownego stojącego na czele prepozytury i kolegium mansjonarzy, a raczej rządcę parafii łączącego beneficjum parafialne ze szpitalnym. Przykładowo $\mathrm{w}$ archidiakonacie pomorskim w XVIII w. nie było w ogóle ufundowanej prepozytury o charakterze wspomnianym wyżej. Były za to w miastach pomorskich tzw. prepozytury szpitalne należące do grupy beneficjów prostych, które dawniej były administrowane przez osobnych kapłanów-prebendarzy zwanych prepozytami szpitalnymi. Po reformacji w niektórych miastach beneficja te zostały włączone do beneficjów parafialnych, a stąd z prestiżowych racji plebani w tych miasteczkach zaczęli tytułować się prepozytami ${ }^{11}$.

Z kolei wśród duchowieństwa pomocniczego wyróżnić można wikariuszy, których zwano manualnymi, w odróżnieniu od wikariuszy wieczystych, których zwykle zatrudniano przy katedrach lub kolegiatach ${ }^{12}$. Natomiast ze względu na

z. 2, s. 48; tenże, Duchowieństwo parafialne diecezji poznańskiej w końcu XVI i w pierwszej polowie XVII wieku, Lublin 1990, s. 25; S. Litak, Parafie w okresie od końca XVI do XVIII wieku, w: Księga Tysiaclecia katolicyzmu w Polsce, red. M. Rechowicz, Lublin 1969, s. 103-104; tenże, Parafie w Rzeczypospolitej, s. 155; J. Kracik, Vix venerabiles. Z dziejów społecznych niższego kleru parafialnego $w$ archidiakonacie krakowskim $w$ XVII-XVIII wieku, Kraków 1982, s. 28; M. Różański, Duchowieństwo parafialne archidiakonatu uniejowskiego $w$ XVIII wieku. Studium prozopograficzne, Łódź 2010, s. 47-48.

${ }^{10}$ Zob. T. Nowicki, Plebani archidiakonatu pomorskiego w XVIII wieku, Lublin 2008, s. 33-37. Por. A. Kopiczko, Duchowieństwo katolickie diecezji warmińskiej latach 1525-1821, Olsztyn 2000, cz. 1, s. 27; J. Szczepaniak, Duchowieństwo diecezji krakowskiej w XVIII wieku. Studium prozopograficzne, Kraków 2010, s. 81 i n.; Litak, Parafie w Rzeczypospolitej, s. 136 i n.; Różański, Duchowieństwo parafialne archidiakonatu uniejowskiego, s. 32.

${ }^{11}$ W XVIII wieku zwano tak np. rządców w Skarszewach, Lęborku, Starogardzie, czasami także w Świeci, Tczewie, Gniewie, Pucku czy Nowym. Co ciekawe źródła ani razu prepozytem nie zwały rządców parafii gdańskiej, która z racji połączenia z Pręgowem, była najbogatszym beneficjum parafialnym $\mathrm{w}$ archidiakonacie. W tym wypadku konsekwentnie stosowano termin parochus Gedanensis (zob. Nowicki, Plebani archidiakonatu pomorskiego, s. 37-42).

${ }^{12}$ Zob. Szczepaniak, Duchowieństwo diecezji krakowskiej w XVIII wieku, s. 89. 
sposób zatrudnienia wikariusza w parafii można ich podzielić na prowizyjnych i aplikacyjnych. Ci pierwsi trafiali na daną parafię w wyniku umowy zawartej z plebanem, która zresztą była w przypadku większości ówczesnego diecezjalnego duchowieństwa podstawą do otrzymania wyższych święceń kapłańskich (tj. subdiakonatu, diakonatu i prezbiteratu), czyli, krótko mówiąc, była to prowizja. $Z$ kolei aplikacja polegała na przydzieleniu wikariusza do danej parafii na polecenie władz kościelnych (biskupa, oficjała) ${ }^{13}$.

O ile wikariusze związani byli ściśle parafią jako bezpośredni pomocnicy plebanów, o tyle pozostały niższy kler był już słabiej związany z duszpasterstwem parafialnym. Do tej kategorii duchowieństwa można zaliczyć wspomnianych już wyżej mansjonarzy współtworzących kolegium duchowne na czele z prepozytem. Zasadniczo mieli oni obowiązek udziału w pracach duszpasterskich, z tej racji, że łączyli często posiadaną mansjonarię z funkcją wikariusza parafialnego ${ }^{14}$. To połączenie wynikało zwykle z utraty lub zmniejszenia uposażenia mansjonarskiego. Jednak z racji obowiązków w prepozyturze (np. obowiązek modlitw za fundatorów, wotywy i oficja o Najświętszej Maryi Pannie, Męce Pańskiej itp.) oraz faktu posiadania prostego beneficjum, można ich porównywać $\mathrm{z}$ wikariuszami wieczystymi z kapituł katedralnych i kolegiackich ${ }^{15}$. Osobną kategorią kleru byli prebendarze. $Z$ duszpasterstwem parafialnym związani pośrednio tylko w sytuacji, gdy posiadane przez nich beneficjum proste $\mathrm{w}$ postaci prebendy znajdowało się w kościele parafialnym. Podobnie, jak w przypadku beneficjów mansjonarskich, także prebendarskie, $\mathrm{z}$ racji malejącego lub od początku niewielkiego uposażenia, mogli obejmować wikariusze, a nawet plebani, niekoniecznie pracujący w tej samej parafii. W zależności od rodzaju prebendy zwano ich promotorami bractw lub prepozytami szpitalnymi. Jeśli w parafii istniało beneficjum proste związane np. z którą́s z bocznych kaplic albo bocznym ołtarzem, to wówczas nazywano ich kapelanami lub altarzystami. Mogli też nosić nazwę kaznodziejów czy penitencjarzy $^{16}$.

Oprócz powyższych grup duchowieństwa, na terenie parafii można spotkać księży wspomagających okresowo kler parafialny. W tej kategorii znajdą się zatem wymieniani niekiedy kapelani prywatni, czasowo angażujący się w pracę pa-

${ }^{13}$ Zob. J. Kracik, Potrydencki system rekrutacji duchowieństwa $w$ diecezji krakowskiej XVI-XVIII wieku, „Analecta Cracoviensia”, 10 (1978) s. 478; tenże, Vix venerabiles, s. 106-117; S. Litak, Zagadnienie parafii w XVI-XVIII wieku, „Znak” 27 (1965) s. 1543-1544; tenże, Struktura i funkcje parafii w Polsce, w: Kościół w Polsce, t. 2, red. J. Kłoczowski, Kraków 1969, s. 324; tenże, Parafie w Rzeczypospolitej, s. 156; M. Różański, Duchowieństwo parafialne archidiakonatu uniejowskiego, s. 51 i n.; J. Szczepaniak, Duchowieństwo diecezji krakowskiej w XVIII wieku, s. 101.

${ }^{14} \mathrm{~S}$. Litak uważa, że należałoby ich nawet zaliczyć do wikariuszy. Z wyników jego badań wynika, że w drugiej połowie XVIII wieku nastąpił całkowity zanik kolegiów mansjonarzy przy kościołach parafialnych. Zob. Litak, Parafie w Rzeczypospolitej, s. 158-161

${ }^{15}$ Zob. Litak, Parafie w Rzeczypospolitej, s. 158 i n.; Różański, Duchowieństwo diecezji krakowskiej w XVIII wieku, s. 65 i n.; Szczepaniak, Duchowieństwo diecezji krakowskiej w XVIII wieku, s. $94 \mathrm{in.}$

${ }^{16}$ Zob. Litak, Parafie w Rzeczypospolitej, s. 162 i n.; Różański, Duchowieństwo diecezji krakowskiej w XVIII wieku, s. 74 i n., Szczepaniak, Duchowieństwo diecezji krakowskiej w XVIII wieku, s. $109 \mathrm{i} \mathrm{n.}$ 
rafialną zakonnicy (zwłaszcza np. w parafiach cysterskich) czy też kler wędrowny bez żadnego utrzymania i niezależny od władz kościelnych, który jednak w końcu badanego okresu albo zanikł całkowicie, albo też nie był odnotowywany w źródłach $^{17}$.

Osobny status $\mathrm{w}$ środowisku parafialnym mieli słudzy kościelni. Jeszcze w XVI wieku byli to czasami duchowni posiadający niższe święcenie, później niemal zawsze ludzie świeccy. Wykonywali oni zadania związane z szeroką działalnością parafii, za co mieli prawo do wynagrodzenia. Spełniali ważną i szczególną rolę wspomagając duchowieństwo w sprawowaniu kultu Bożego lub wypełnianiu funkcji charytatywno-edukacyjnych. Po pierwsze wymienić wypada kantorów, później coraz częściej zastępowanych przez organistów, następnie zakrystianów i dzwonników, choć rzadziej spotykanych w parafiach. Wyjątkowo w źródłach wizytacyjnych pojawiali się grabarze i wspomagający organistów kalikanci. W pewnym zakresie funkcje pomocnicze mogli spełniać tzw. mendici, pauperculi czy seniculi, czyli po prostu podopieczni przyparafialnych przytułków. Niemal w każdej parafii był przez wizytatorów odnotowywany avus, czyli dziad, dziadek kościelny. Wymienione terminy nie wskazują na konkretne zadania służebne w parafii, ale może właśnie wśród biednych i dziadów kościelnych należy szukać dzwonników, grabarzy czy kalikantów zwykle osobno nie wymienianych w źródłach. a może i niekiedy nawet zakrystianów, których równie rzadko odnotowują wizytacje kanoniczne. Niemal na pewno ci ludzie wykonywali prace porządkowe w świątyni i jej otoczeniu, prali bieliznę kapłańską i ołtarzową, dbali o paramenty i kościelne sprzęty. Bez wątpienia niezwykle ważną rolę pełnili w środowiskach parafialnych bakałarze, czyli nauczyciele, którzy prowadzili szkoły parafialne, stosunkowo liczne zwłaszcza w archidiakonacie pomorskim. Bardzo często zresztą łączyli oni funkcje edukacyjne i muzyczne, wcześniej jako kantorzy, potem, szczególnie od 2. połowy XVII w., jako organiści. Do grupy sług kościelnych należy również zaliczyć ministrantów, o których jednak brakuje bezpośrednich wzmianek. Najpewniej należy ich szukać przede wszystkim uczniów parafialnych szkół. Niemniej w wielu parafiach odnotowywane były małe komże lub dalmatyczki. Można zatem wnioskować, że chłopcy pełnili służbę przy ołtarzu. I ostatnią, choć specyficzną grupą personelu pomocniczego były położne. Wprawdzie trudno je uznać ściśle za służbę kościelną. Nie były przecież bezpośrednio wynagradzane przez Kościół. Niemniej podlegały one kontroli plebanów. Ważne było, by wykwalifikowane akuszerki w skrajnych sytuacjach zagrożenia życia umiały udzielić nowo narodzonemu dziecku sakramentu chrztu. Przyuczano je więc, kontrolowano, ewidencjonowano, egzaminowano. Na te sprawy często zwracało uwage prawo synodalne oraz wizytatorzy biskupi ${ }^{18}$.

Należy jeszcze zakreślić granice terytorialne dawnej, przedrozbiorowej diecezji włocławskiej. Składała się z trzech archidiakonatów, tj. włocławskiego obej-

${ }^{17}$ Zob. Litak, Parafie w Rzeczypospolitej, s. 166-168; Szczepaniak, Duchowieństwo diecezji krakowskiej w XVIII wieku, s. 119; Jabłońska, Funkcje społeczne parafii archidiakonatu gnieźnieńskiego w XVII wieku, s. 10-12.;

${ }^{18}$ Por. Litak, Parafie w Rzeczypospolitej, s. 168-173; Nowicki, Ministri ecclesiae, s. 72-88; Jabłońska, Funkcje społeczne parafii archidiakonatu gnieźnieńskiego w XVII wieku, s. 45-79. 
mującego wschodnie Kujawy zbliżonego terytorialnie do województwa brzesko-kujawskiego z Włocławkiem, Brześciem Kujawskim i Radziejowem. Następnie archidiakonatu kruszwickiego z Kruszwicą, Bydgoszczą i Inowrocławiem. Teren ten zasadniczo odpowiadał województwu inowrocławskiemu. Z kolei w północnej części diecezji znajdował się archidiakonat pomorski obejmujący $2 / 3$ dawnego województwa pomorskiego (bez jego południowo-zachodniej części należącej do archidiecezji gnieźnieńskiej). Największym miastem w archidiakonacie pomorskim był oczywiście Gdańsk, a z mniejszych Świecie na południu, Starogard i Tczew w środkowej części oraz Puck na północy.

Południkowe ukształtowanie tego terytorium, ale także odmienne losy polityczne tych ziem sprawiły, że diecezja włocławska wyraźnie dzieliła się na dwie części. Po spojrzeniu na mapę widać od razu, że archidiakonat pomorski stanowi wyodrębnioną geograficznie całość ${ }^{19}$. Co więcej, jego powierzchnia wynosząca $11656 \mathrm{~km}$ kw., to ponad 63\% całego obszaru diecezji. Archidiakonaty kujawskie - włocławski i kruszwicki łącznie nie były większe niż archidiakonat pomor$\mathrm{ski}^{20}$. Ponadto nieco inne były wcześniejsze dzieje polityczne ziem wchodzących w skład diecezji włocławskiej. To zaś kształtowało odrębności, których początki sięgały średniowiecza. Znalazły one swój wyraz także w ramach życia kościelnego diecezji. Wystarczy wspomnieć, że w XVI wieku pojawiło się w tytulaturze biskupa Stanisława Karnowskiego sformułowanie episcopus Wladislaviensis et Pomeraniae, stosowane potem stale przez jego następców ${ }^{21}$. W źródłach, zwłaszcza wizytacjach parafii pomorskich, nader często używano określenia diecezja pomorska zamiast archidiakonat ${ }^{22}$. Taka tradycja i zwyczaj zostały w pewien sposób usankcjonowane w 1765 roku. Wówczas biskup Antoni Ostrowski wraz z kapitułą wystąpił do Stolicy Apostolskiej o ustanowienie dla Pomorza osobnego biskupa, faktycznie pełniącego funkcje pomocnicze w diecezji włocławskiej. Prośba zyskała poparcie króla, co przyspieszyło sprawę w Rzymie. Papież Klemens XIII w lutym 1766 roku prekonizował pierwszego biskupa pomorskiego

${ }^{19}$ Zob. S. Litak, Atlas Kościoła łacińskiego w Rzeczypospolitej Obojga Narodów w XVIII wie$k u$, Lublin 2006, s. 120-121.

${ }^{20}$ Por. S. Litak, Kościół łaciński w Rzeczypospolitej około 1772 roku, Lublin 1996, s. 124; tenże, Atlas Kościoła łacińskiego, s. 91.

${ }^{21}$ Tytuł taki nakazano używać na synodzie prowincjonalnym w Piotrkowie odbytym w $1551 \mathrm{r}$. (zob. J. Gręźlikowski, Recepcja reformy trydenckiej $w$ diecezji włocławskiej w świetle ustawodawstwa synodalnego, Włocławek 2000, s. 109). Przykładowo w nagłówku do statutów synodalnych diecezji włocławskiej z 1568 r. czytamy: Stanislaus Carncovius, Dei gratia, Wladislaviensis et Pomeraniae Episcopus (zob. Statuta synodalia Dioecesis Wladislaviensis et Pomeraniae, collegit et edidit Zeno Chodyński, Varsaviae 1890, s. 38). We wcześniejszym synodzie z 1539 r. biskup Łukasz Górka, tak jak i jego poprzednicy, użył w swojej tytulaturze tylko Episcopus Wladislaviesis (zob. tamże, s. 36).

${ }^{22}$ Przykładowo duchownych pochodzących $\mathrm{z}$ archidiakonatu pomorskiego określano najczęściej jako pochodzących z diecezji pomorskiej. Zob. T. Nowicki, Die territoriale Herkunft der katholischen Geistlichkeit im Archidiakonat Pommerellen im 18. Jahrhundert, „Zeitschrift für Ostmitteleuropa-Forschung", 49 (2000) Hf. 1, s. 24. 
Cypriana Wolickiego ${ }^{23}$. Mianowanie biskupa, który za siedzibę miał Gdańsk, potwierdzało wyjątkowe różnice pomiędzy częścią kujawską i pomorską diecezji włocławskiej.

Przejdźmy już do zasadniczego tematu artykułu. Chcąc dobrze scharakteryzować pewną homogeniczną grupę ludzką należy przeprowadzić szeroką kwerendę źródłową. Jest to łatwiejsze, gdy można skorzystać ze źródła zbierającego obszerne i jednorodne informacje, jak na przykład współczesne akta osobowe. W przypadku okresu przedrozbiorowego nie mamy jednak do czynienia tego typu archiwaliami. Należy zatem prowadzić poszukiwania o konkretnych osobach w różnym różnorodnym materiale źródłowym.

Do badań nad duchowieństwem i służbą kościelną najważniejszym rodzajem źródeł są bez wątpienia akta wizytacyjne. Te dotyczące diecezji włocławskiej są obecnie przechowywane w trzech różnych archiwach diecezjalnych. Co ciekawe, obecne miejsca przechowywania odpowiadają w dużym przybliżeniu dawnemu podziałowi diecezji na archidiakonaty. I tak wizytacje archidiakonatu włocławskiego zgromadzone są w Archiwum Diecezjalnym we Włocławku ${ }^{24}$. Z kolei akta dotyczące dawnego archidiakonatu kruszwickiego zostały zarchiwizowane w Archiwum Archidiecezjalnym w Gnieźnie ${ }^{25}$. Natomiast w Archiwum Diecezjalnym w Pelplinie przechowywane są wizytacje parafii dawnego archidiakonatu pomorskiego ${ }^{26}$. Uogólniając akta wizytacji dotyczące diecezji włocławskiej to 99 ksiąg obejmujących okres od 2. połowy XVI do początku XIX wieku.

Wizytacje mają różny zakres geograficznym. Znaleźć można zatem wizytacje o charakterze generalnym, które przekrojowo obejmują całą diecezję włocławską. Są takie, które dotyczą jedynie poszczególnych archidiakonatów, ale są także księgi obejmujące pojedyncze dekanaty lub nawet pojedyncze parafie. Akt wizytacyjne mają też różny zakres informacyjny. Inaczej mówiąc, przekazują mniej lub więcej informacji o duchowieństwie parafialnym i służbie kościelnej27.

W przypadku źródeł wizytacyjnych dotyczących parafii diecezji włocławskiej możliwe jest uzyskanie kilku w miarę pełnych przekrojów chronologicznych obejmujących całą diecezję, a mianowicie:

\footnotetext{
${ }^{23}$ Chodyński, Biskupi sufragani włocławscy, Włocławek 1906, s. 86-87.

${ }^{24}$ We Włocławku zarchiwizowano 67 jednostek archiwalnych z lat 1582-1791.

${ }^{25}$ Archiwum gnieźnieńskie przechowuje 10 ksiąg wizytacyjnych obejmujących dawny archidiakonat kruszwicki. Zakres chronologiczny zamyka się w latach 1582-1801.

${ }^{26} \mathrm{~W}$ archiwum zebrano 22 księgi wizytacji z lat 1583-1819.

${ }^{27}$ Zob. S. Librowski, Wizytacje diecezji kujawskiej, cz.1: wizytacje diecezji kujawskiej i pomorskiej, t. 1: Opracowanie archiwalno-źródtoznawcze, „Archiwa, Biblioteki i Muzea Kościelne” (dalej: ABMK) 8 (1964), s. 5-186; tenże, Wizytacje diecezji włocławskiej, cz. 1: wizytacje diecezji kujawskiej i pomorskiej, t. 1: Opracowanie archiwalno-źródłoznawcze, z. 2: Wizytacje w latach 1123-1421, ABMK, 10 (1965) s. 35-206; S. Litak, Akta wizytacyjne parafii z XVI-XVIII wieku jako źródto historyczne, „Zeszyty Naukowe KUL”, 5 (1962) nr 3, s. 41-58; tenże, Parafie w Rzeczypospolitej, s. 30-31; B. Szady, Wizytacje diecezji chetmskiej w XVII wieku, ABMK, 82 (2004) s. 269287; T. Nowicki, Źródła do badań biograficznych nad osiemnastowiecznym katolickim duchowieństwem parafialnym, „Studia Archiwalne”, 1 (2004) s. 102-103.
} 
1. 2. połowa XVI wieku - wizytacje bpa Hieronima Rozdrażewskiego ${ }^{28}$, 2. lata 1710-1712 - wizytacja generalna bpa Konstantego Felicjana Szaniawskie$\mathrm{go}^{29}$,

3. lata 1763-1766 - wizytacja generalna bpa Antoniego Kazimierz Ostrowskie$\mathrm{go}^{30}$

4. lata 1779-1781 - wizytacja generalna bpa Józefa Ignacego Rybińskiego ${ }^{31}$.

Z zestawienia widać, że szczególnie dotkliwy jest brak całościowego zestawienia dla XVII wieku. Wprawdzie można znaleźć dla tego stulecia przekroje obejmujące np. parafie jednego archidiakonatu, ale tak naprawdę reprezentacyjne będą tylko wizytacje archidiakonatu włocławskiego z lat 1632-1647 przechowywane we Włocławku ${ }^{32}$ oraz akta $\mathrm{z}$ wizytacji biskupa Madalińskiego $\mathrm{z}$ lat 16861687 przechowywane w Pelplinie ${ }^{33}$. Z kolei dla przełomu XVII i XVIII wieku zachowały się akta wizytacji parafii pomorskich i kruszwickich, zaginęła natomiast księga, która obejmowała parafie archidiakonatu włocławskiego. ${ }^{34}$

Istotniejszy wydaje się jednak sam zakres informacji o duchowieństwie i służbie kościelnej w protokołach wizytacyjnych, a ten bywał różnorodny. W przypadku duchowieństwa w wizytacjach o bardziej rozbudowanych kwestionariuszach podawano wiele danych, czasem niezwykle szczegółowych. Informowano o funkcji pełnionej w parafii przez kapłana, podawano jego imię i nazwisko, określano jego wiek w chwili wizytacji, czasem rok urodzenia, rzadziej ścisłą datę. Wizytatorzy pisali, skąd kapłan pochodzi - te dane mogły być bardzo precyzyjne, często odnoszące się do konkretnej miejscowości czy parafii. Ale mogły być również bardziej ogólne - podawano np. powiat, dekanat, województwo czy diecezję, a w przypadku obcokrajowców kraj pochodzenia. Znacznie rzadziej określano pochodzenie stanowe (szlachta, mieszczaństwo, chłopstwo).

Kolejną ważną grupą informacji były dane o wykształceniu. Pojawiały się zapisy informujące nie tylko o ukończonym kolegium czy seminarium, ale i bardziej szczegółowe mówiące o latach studiów, przedmioty czy uzyskanych stopniach

${ }^{28}$ We Włocławku przechowywane są cztery księgi obejmujące parafie wszystkich trzech archidiakonatów diecezji. Z kolei w Pelplinie zarchiwizowano księgę z czasów biskupa Rozdrażewskiego obejmującą parafie archidiakonatu pomorskiego. Natomiast w Gnieźnie znajduje się księga tych wizytacji obejmująca parafie archidiakonatu kruszwickiego. Zob. bibliografia.

${ }^{29}$ Księgi tej wizytacji dla poszczególnych archidiakonatów przechowywane są we Włocławku (2 księgi), Pelplinie (1 księga) i Gnieźnie (1 księga). Zob. bibliografia.

${ }^{30}$ We Włocławku zarchiwizowano trzy księgi obejmujące dekanaty archidiakonatu włocławskiego, w Pelplinie cztery obejmujące parafie archidiakonatu pomorskiego, w Gnieźnie zaś jedną dla archidiakonatu kruszwickiego. Zob. bibliografia.

${ }^{31}$ Siedem ksiąg tej wizytacji dla parafii archidiakonatu włocławskiego oraz dodatkowo księga dla dekanatu świeckiego i fordońskiego znajduje się we Włocławku. Ponadto w tym archiwum przechowywane są trzy księgi dekretów reformacyjnych. Kolejne cztery księgi dla parafii pomorskich są w Pelplinie, a jedna w Gnieźnie. Zob. bibliografia.

${ }^{32}$ Chodzi w tym przypadku o wizytacje przeprowadzane w czasach rządów biskupa Wojciecha Łubieńskiego. Zob. bibliografia. Por. S. Olczak, Kościoły parafialne $w$ archidiakonacie włocławskim XVI-XVIII w., Lublin 2004, s. 15.

${ }^{33}$ Zob. bibliografia.

${ }^{34}$ Zob. bibliografia. 
uniwersyteckich. Edukacja teologiczno-filozoficzna dawała możliwość otrzymania poszczególnych stopni święceń. Wobec tego zapisy wizytacyjne często odnotowywały szafarzy święceń, miejsce i czas uzyskania poszczególnych stopni, informowały o tytule do święceń wyższych, czasem o mszy prymicyjnej. Jednak tego typu dane pojawiają się częściej w wizytacjach z 2. połowy XVIII wieku, we wcześniejszych występują sporadycznie.

Informacji o kapłanach dotyczyły też niekiedy ich rezydencji i kumulacji beneficjów, zwłaszcza że od Soboru Trydenckiego wymagano od duchownych stałego pobytu w parafii i zakazywano kumulacji. Jeśli takie sytuacje miały miejsce, wizytator informował np. o dyspensach. Przy tej okazji wspominano o innych funkcjach kapłana, czy to w kościelnej administracji terenowej (dziekan, archidiakon), czy w administracji sądowej (np. w sądzie biskupim lub konsystorskim), czy też np. w otoczeniu biskupa (np. jako jego kapelan lub też jako członek jego dworu $)^{35}$.

Pojawiały się również inne informacje, w zależności od tego, na jakie elementy zwracał uwagę szczegółowy kwestionariusz wizytacyjny zaakceptowany przez władze kościelne. Osobną kwestią pozostają zwykle bardzo szczegółowe, drobiazgowe i niezwykle obszerne opisy uposażenia beneficjum, czasami w rozróżnieniu na uposażenie stricte beneficjalne, przeznaczone dla plebana, oraz to, które służyło utrzymaniu tzw. fabryki kościoła ${ }^{36}$.

Przechodząc do informacji o służbie kościelnej zaangażowanej w pracę w parafii, trzeba stwierdzić, że w porównaniu z duchowieństwem, dane o tej grupie ludzi były już mniej szczegółowe. O ile jeszcze o najważniejszych sługach kościelnych, jak organista czy nauczyciel, czasem zakrystian, informowano w miarę dokładnie, o tyle o innych którzy rzadziej występowali w środowisku parafialnym, często milczano lub podawano jedynie informacje o ich obecności, nie wchodząc w bardziej konkretne opisy. Mimo to można podjąć próbę zebrania informacji o sługach danego kościoła parafialnego. Oczywiście głębia informacyjna i zakres zebranych danych zależał od kwestionariusza wizytacyjnego. Jeśli jednak w parafii występował któryś z ministrów, wówczas przynajmniej podawano jego funk-

${ }^{35}$ Por. Olczak, Duchowieństwo, s. 32; T. Walachowicz, Kumulacja beneficjów, EK, t. 10, red. E. Ziemann, Lublin 2004, kol. 224; Nowicki, Plebani archidiakonatu pomorskiego, s. 57-67; Szczepaniak, Duchowieństwo diecezji krakowskiej w XVIII w., s. 322 i n.

${ }^{36} \mathrm{~W}$ sprawie rozróżniania uposażenia plebańskiego o uposażenia przeznaczonego na kościół zob. Zob. K. Karłowski, Z dziejów zarząu majątku kościelnego, „Miesięcznik Kościelny. Organ Archidiecezji Gnieźnieńskiej i Poznańskiej”, 51 (1936) s. 209-210; S. Sołtyszewski, Dochody kościelne pod zarządem witrykusów w polskim ustawodawstwie synodalnym, „Prawo Kanoniczne”, $3(1960) \mathrm{nr} 3-4$, s. 312; tenże, Zarząd majątkiem kościelnym w kanonicznym ustawodawstwie powszechnym, „Prawo Kanoniczne”, 3 (1960) nr 3-4, s. 335-336; J. Wiśniewski, Fabrica ecclesiae na terenie oficjalatu pomezańskiego $w$ świetle wizytacji biskupów XVII-XVIII w., cz. 1, „Archiwista Polski”, 12 (2007) nr 2, s. 50; T. Nowicki, Uposażenie kleru parafialnego w archidiakonacie pomorskim w XVIII wieku, „Roczniki Humanistyczne”, 51 (2003) z. 2, s. 48; tenże, Carbona ecclesiae przyczynek do badań nad dochodowością kościołów parafialnych $w$ archidiakonacie pomorskim na przykładzie wizytacji biskupa Rybińskiego z 1780-1781 roku, „Studia Pelplińskie”, 42 (2010), wyd. specjalne, s. 249; tenże, Dos ecclesiae and dos parochii illustrated with an example of the canonical visitation of the parishes in the diocese of Wtoctawek in the years 1710-1711, ABMK, 106 (2016) s. 101-112. 
cję, czasami imię i nazwisko, znacznie rzadziej pochodzenie terytorialne, wiek w chwili wizytacji, lata służby, a już zupełnie wyjątkowo określano pochodzenie środowiskowe czy stanowe. Jeśli sługa kościelny pełnił różne role w parafii, czyli po prostu łączył funkcje przypisane kilku sługom kościelnym, wówczas również wizytator o tym wspominał. Czasami informował o postawie moralnej i zaangażowaniu w wykonywanie obowiązków, a w przypadku organistów o zdatności do zawodu ${ }^{37}$.

$\mathrm{W}$ archidiakonacie pomorskim, z racji wyjątkowego uposażenia przeznaczonego dla nauczycieli i organistów, bardzo często znaleźć można rozbudowane zapisy dotyczące wynagradzania sług kościelnych. Wizytatorzy niezwykle skrupulatnie, podobnie zresztą jak przy uposażeniu kapłanów (oczywiście przy zachowaniu proporcji wynikających $\mathrm{z}$ różnorodności i wysokości uposażenia) informowali o stałej pensji otrzymywanej zwykle z pieniędzy przeznaczonych na utrzymanie kościoła (nie z beneficjum plebańskiego). Podawali szczegółowe dane o tzw. kantopornym (kwartałowym, chlebowym), czyli opłatach pieniężnych, jakie dostawali bezpośrednio od wszystkich parafian głównie organiści (rzadziej nauczyciele). Na dochody sług kościelnych składały się również czynsze z legat i zapisów, uzupełniające przychody np. za obsługę nabożeństw brackich. Szczególną rolę odgrywały różnorodne świadczenia w pieniądzu lub naturze, jak np. tzw. wiertlowe (meszne, dziesięcina, taca), kolęda w okresie bożonarodzeniowym czy paschalia w okresie wielkanocnym, różnego rodzaju naturalia czy akcydensy (np. zwłaszcza przy okazji ślubów i pogrzebów). Źródła wizytacyjne informowały również o prawach rzeczowych przynależnych sługom kościelnym (np. darmowe mieszkanie w budynkach kościelnych i prawo do niepłacenia podatków publicznych, darmowe stołowanie się na koszt plebana, wolny połów ryb, wolny wyrąb lasu). Niekiedy znajdziemy wiadomości o prawie do użytkowania czy odnajmowania różnych kościelnych nieruchomości, jak domy czy grunty, z czego również czerpano czasem niemałe dochody ${ }^{38}$.

Drugą, niezwykle ważną grupą źródeł do badań zwłaszcza nad duchowieństwem parafialnym, są kościelne księgi proweniencji sądowej. Chodzi o dokumentację powstałą w wyniku działania oficjałów i urzędów konsystorskich ${ }^{39}$. Zasób dotyczący konsystorzy diecezji włocławskiej zgromadzony jest zasadniczo we Włocławku (konsystorz generalny włocławski) oraz w Pelplinie (konsystorz generalny gdański). W sumie na zespoły obu konsystorzy składa się kilkaset różnego rodzaju ksiąg (czystopisowych indukt i brudnopisowych protokołów). Co ważne, są to nie tylko wpisy dotyczące spraw sądowych, ale także spraw administracyjnych, które uzupełniają znacząco informacje o duchowieństwie. Szczególnie przydatne są wpisy dotyczące instytucji i rezygnacje z beneficjów, zgody na administrowanie wakującymi beneficjami, zapisy udzielające komend. Istotną kategorią są zapisy prowizji dla wikariuszu udzielane przez plebanów i wciąga-

${ }^{37}$ Zakres informacji dotyczących sług kościelnych zob. Nowicki, Ministri ecclesiae, passim.

${ }^{38} \mathrm{O}$ szczegółach uposażenia personelu pomocniczego w parafiach diecezji włocławskiej zob. tamże, s. 327 i n.

${ }^{39}$ Tenże, Źródła do badań, s. 103-104. O konsystorzach zob. S. Chodyński, Konsystorze w diecezji kujawsko-pomorskiej, Włocławek 1914. 
ne do akt konsystorza. Oczywiście, jako księgi sądowe, zawierają one również szereg informacji na temat konfliktów, zatargów, spraw spornych dotyczących nie tylko duchowieństwa, lecz także osób świeckich. Trzeba jednak zaznaczyć, że korzystanie z ksiąg konsystorskich wymaga znacznego zaangażowania czasowego. Ponadto badacz może napotkać spore trudności wynikające chociażby z faktu, że niektóre księgi mają charakter brudnopisowy, a protokoły prowadzone są różną ręką, zawierają różnorodne dodatkowe pisma procesowe. Warto dodać, że w korzystaniu z ogromu informacji zawartych w konsystorskich księgach sądowych mogą służyć umieszczane niekiedy na końcu ksiąg alfabetyczne indeksy zawartości ${ }^{40}$.

Innym rodzajem źródeł, w których bez wątpienia znaleźć można informacje o duchowieństwie, są księgi pochodzące z zadwornej kancelarii biskupiej ${ }^{41}$. Dla dawnej diecezji włocławskiej ten rodzaj źródeł przechowywany jest przede wszystkim we Włocławku. Można powiedzieć, że zasadniczy trzon ksiąg wytworzonych przez kancelarię ordynariusza, w którym można szukać informacji potrzebnych do zbiorowej charakterystyki duchowieństwa, ma charakter podobny do ksiąg konsystorskich. Wpisywano tam zatem wykonywane czynności przed sądem biskupim, udzielano instytucji na beneficja, przyjmowano rezygnacje. W kancelarii biskupiej wpisywano najczęściej dokumenty dotyczące beneficjów kapitulnych, a rzadziej parafialnych.

Specyficzny rodzaj ksiąg stanowią księgi czynności pontyfikalnych, a wśród nich najciekawsze z punktu widzenia prozopografii, czyli księgi święceń. Te ostatnie najczęściej powstawały w wyniku działania biskupów pomocniczych, gdyż to oni zwykle w okresie staropolskim udzielali święceń. W przypadku diecezji włocławskiej 11 tego typu ksiąg przechowuje Archiwum Diecezjalne we Włocławku. Wartość takich źródeł jest nieoceniona. Przedstawiają one bowiem kleryka w konkretnym momencie czasowym, w którym dany biskup udzielił mu konkretnego rodzaju święceń. Zapisy takie precyzyjnie określają czas i miejsce obrzędów, informują o tytule, na podstawie którego dopuszczono go do święceń, czasem podając dane o postępach $\mathrm{w}$ nauce i o formacji seminaryjnej. Te szczegółowe informacje same w sobie mogą być przydatne do szczegółowych analiz dotyczących kleru parafialnego ${ }^{42}$.

${ }^{40}$ Liczne przykłady zindeksowanych wpisów zawierają indukty konsystorza gdańskiego. Pierwsze tego typy indeksy spotkać można już w księdze z 1. 1592-1595: Index Rerum notabilium in his actis conotatarum (ADPel, Acta Consistorii Gedanensis, sygn. G2, k. 214-214v)

${ }^{41}$ Nowicki, Źródła do badań, s. 104.

${ }^{42}$ Zob. S. Olczak, Jezuici otrzymujący święcenia z rąk biskupów poznańskich na przełomie XVI/ XVII wieku, „Roczniki Humanistyczne”, 31 (1983) z. 2, s. 85-104; tenże, Diecezjanie płoccy w poznańskich księgach święceń z przełomu XVI i XVII stulecia, „Studia Płockie”, 13 (1985) s. 91-112; tenże, Poznańskie księgi święceń jako źródto do badań nad cystersami, w: Historia i kultura cystersów $w$ dawnej Polsce i ich europejskie zwiazki, Poznań 1987, s. 489-498; T. Nowicki, Terminy udzielania święceń kapłańskich w XVIII wieku na przykładzie księgi święceń biskupa Franciszka Kanigowskiego, w: Archiva temporum testes, Źródła historyczne jako podstawa pracy badacza dziejów. Księga pamiątkowa ofiarowana Profesorowi Stanistawowi Olczakowi, red. G. Bujak, T. Nowicki, P. Siwicki, Lublin, 2008, s. 384-393; tenże, Terminy święceń na przyktadzie księgi czynności 
W badaniach nad duchowieństwem i służbą kościelną nie można również pominąc dokumentacji wytworzonej przez same parafie. Chodzi w tym wypadku o coraz liczniej występujące od czasów Soboru Trydenckiego księgi metrykal$\mathbf{n e}^{43}$. Zaletą jest bez wątpienia systematyczność ich tworzenia i ciągłość występowania. Wprawdzie mogą one spełniać tylko funkcję pomocniczą, ale pozwalają uzyskać dynamikę opisu duchowieństwa, zwłaszcza przez pryzmat występowania konkretnego kapłana w danej parafii. Zestawienie informacji o kapłanie i daty dziennej udzielonego sakramentu bądź przewodniczenia obrzędom pogrzebowym, umożliwia ustalenie przybliżonego okresu pracy tego księdza w konkretnej parafii. Oczywiście te przekazy są wtedy bardziej wartościowe, kiedy zostaje spełniony warunek ciągłości zapisów metrykalnych. Najcenniejsze i najbardziej wartościowe są księgi ochrzczonych z tej racji, że chrztów udzielano najczęściej. Wraz z metrykami dotyczącymi ślubów i pogrzebów mogą być czasem jedynym źródłem informacji o pracy duchownego w danej parafii, szczególnie, gdy pojawiał się w niej na krótko lub całkowicie okazjonalnie. Dodatkowo w metrykach można spotkać zapisy informujące o objęciu beneficjum przez nowego plebana czy o założeniu przez niego nowej księgi metrykalnej. Dokładna kwerenda pozwala wychwycić informacje o sakramentach przyjmowanych przez osoby służące kościołowi, o chrztach ich dzieci, a także wpisy informujące o śmierci księdza lub sługi kościelnego. Utrudnieniem w korzystaniu z metryk może być ich znaczne rozproszenie - często przechowywane są w poszczególnych parafiach, nie zaś $\mathrm{w}$ archiwach diecezjalnych, choć akurat w przypadku sporej części parafii, akta zebrano w archiwach diecezjalnych ${ }^{44}$.

Warto też wspomnieć o innych rodzajach źródeł, które często zawierają cenne, czasem nowe, a czasem uzupełniające informacje o duchowieństwie. Wystarczy wymienić metryki kolegiów czy seminariów ${ }^{45}$, klasztorne księgi zmarłych ${ }^{46}$, opisy kościołów i parafii sporządzane przez różnych autorów, w których mogą

pontyfikalnych biskupa Wojciecha Bardzińskiego z lat 1709-1723, w: Kapłan, historyk, pedagog. Księga pamiątkowa ks. infulata dra Stanisława Grada z okazji 70-lecia urodzin i 35-lecia pracy dydaktycznej w Wyższym Seminarium Duchownym w Łodzi, red. M. Różański, Łódź 2013, s. 267-278.

${ }^{43}$ Por. Nowicki, Źródła do badań, s. 104-105. Zob. zestawienie ksiąg metrykalnych dla parafii archidiakonatu pomorskiego: M. Stanke, Katholische Kirchenbücher in Ost- und Westpreussen (Stand 1999), Bonn 2000.

${ }^{44}$ Przykłady wykorzystania ksiąg metrykalnych w badaniach nad duchowieństwem zob. T. Nowicki, Stownik biograficzny rządców parafii archidiakonatu pomorskiego w osiemnastym wieku, Lublin 2004.

${ }^{45}$ Przykładowo ważne także dla diecezji włocławskiej wydane przez Georga Lühra metryki $\mathrm{z}$ terenu Warmii, jak Die Matrikel des päpstlichen Seminars zu Braunsberg 1578-1798, Braunsberg 1925, 1926; Die Schüller des Braunsberger Gymnasiums von 1694 bis 1776, w: Monumenta Historiae Warmiensis, Lieferung 36-38, Bd. XII, hrsg. G. Lühr, Braunsberg 1932-1934; Die Schüler des Rösseler Gymnasium nach dem Album der Marianischen Kongregation, von G.Lühr, „Zeitschrift für die Geschichte und Altertumskunde Ermlande“, 15 (1905) s. 391-464, 579-704; 16 (1910) s. 158312; 17(1910), s. 1-144; 18 (1913) s. 138-167.

${ }^{46}$ Dla przykładu Liber mortuorum monasterii Coronoviensis O.Cist., wyd. A. Mańkowski, „Fontes Towarzystwa Naukowego w Toruniu”, 25 (1931); Das Totenbuch des Prämonstratenserinnen-Kloster Zuckau bei Danzig, hrsg. von M.Perlbach, w: Quellen und Darstellungen zur Geschich- 
być zawarte np. wykazy plebanów ${ }^{47}$. Pomocne mogą okazać się akta kapitulne, zwłaszcza instalacje na beneficja i protokoły posiedzeń. Dla okresu od połowy XVIII wieku pewne informacje przynoszą coraz częściej publikowane schematyzmy diecezjalne ${ }^{48}$. Nie można zapominać również o źródłach proweniencji świeckiej, np. aktach miejskich, w których bez wątpienia pojawiały się informacje o kapłanach czy sługach kościelnych, którzy w małomiasteczkowych środowiskach należeli do lokalnej elity społecznej.

Reasumując należy zaznaczyć, że badania nad charakterystykami grupowymi społeczeństwa przedrozbiorowego, w tym także duchowieństwa parafialnego i służby kościelnej z diecezji włocławskiej, wymagają dotarcia do różnorodnych źródeł. Jak wcześniej już wspomniano, dla okresu staropolskiego brak jednolitego materiału w postaci znanych z późniejszego okresu rozwoju kancelarii akt osobowych, w których znalazłyby się najważniejsze dane o kapłanach i sługach kościelnych. Dotarcie do szczegółowych informacji, ich skorelowanie, uzupełnienie, zanalizowanie wymaga wiele pracy i wysiłku, a nie zawsze jej efektywność jest zadawalająca. Co więcej kwerendę archiwalną należy przeprowadzać nie tylko w oparciu o różnorodne rodzaje dokumentacji, ale także w różnych archiwach, co jest jeszcze jednym poważnym utrudnieniem. Dla badań nad klerem i służbą parafialną dawnej diecezji włocławskiej nieodzowne są wizyty w archiwach kościelnych we Włocławku, Gnieźnie i Pelplinie. Wspomniane trudności i problemy nie oznaczają bynajmniej, że badania prozopograficzne nad wiodącymi grupami parafialnego środowiska są niewykonalne. Analiza zachowanych źródeł odnoszących się do diecezji włocławskiej umożliwia bez wątpienia opracowanie odpowiedniej relacyjnej bazy danych duchowieństwa parafialnego oraz służby kościelnej. Narzędzie takie nie tylko powinno pozwalać na selekcję informacji przez pryzmat określonego czasu i terenu, lecz mogłoby zostać połączone na przykład z geobazą ArcGIS, co umożliwiłoby ukazanie wyników także w przestrzeni geograficznej. Finalnie opracowanie tego typu bazy powinno obejmować środowiska parafialne nie tylko z diecezji włocławskiej, lecz również z innych polskich diecezji. Aplikacja elektroniczna mogłaby zresztą być otwarta także np. dla duchowieństwa Kościoła grekokatolickiego czy nawet dla innych wyznań. Opracowanie takiego szerokiego narzędzia elektronicznego pozwoliłoby i ułatwiło charakterystykę osób związanych z Kościołem czy religią w ogóle w przedrozbiorowej Rzeczypospolitej.

te Westpreussens, Danzig 1906, s. 189-222; G. Kloskowski, Sylwetki cystersów pelplińskich w nekrologach i kronice, „Studia Pelplińskie”, 44 (2011) s. 151-302.

${ }^{47} \mathrm{~Np}$. wydane Ad historiam ecclesiasticam Pomeraniae apparatus pauper subsidia literaria poscens a viris bonis et doctis cellectus ad interim a Georgio Schwengel Carthusiae priore 1749, curavit Bruno Czapla, „Fontes Towarzystwa Naukowego w Toruniu”, 16/19 (1912-1915) czy też znajdujące się w Archiwum Diecezjalnym w Pelplinie dzieło ks. Jana Borcka z 1765 r. (ADPel., cz. I, sygn. V8; cz. II, sygn. V9)

${ }^{48}$ Pierwsze drukowane schematyzmy dla archidiakonatu pomorskiego zawierające informacje o obsadzie parafialnej pojawiają się od lat 80 . XVIII wieku. O rubrycelach i schematyzmach dotyczących dawnej diecezji włocławskiej pisał S. Librowski, Katalog rubrycel i schematyzmów diecezji i zakonów historycznej Polski znajdujących się w księgozbiorze podręcznym Archiwum Diecezjalnego we Włoctawku, cz. 1: Rubrycele i schmatyzmy diecezjalne, ABMK, 25 (1972) s. 39-113. 


\section{BIBLIOGRAFIA}

\section{Źródla rękopiśmienne}

Archiwum Archidiecezjalne w Gnieźnie

Zespół: Akta Konsystorza Gnieźnieńskiego

sygn. E1, [Visitationes ecclesiarum archidiaconatu Crusviciensis 1582-1597].

sygn. E7, Visitatio ecclesiarum parochialium in archidiaconatu Crusvcensi consisten ex mandato et commisione (...) Stanislai de Lubraniec Dąmbski, epi Vladislaviensi et Pomeraniae per Joannem Michtarowski, archidiaconum Crusvicensem, canonicum Vladislaviensem ... in Anno Millesimo sexacentessimo nonagessimo nono expedita.

sygn. E8,Visitatio archidaconatus Crusvicensis ex mandato (...) Constantini Szaniawski Dei et Apostolicae Sedis gratia episcopi Cuiaviensis et Pomeraniae per (...) Paulum Wolski, cancelarium Vladislaviensem archidiaconum Crusvicensem expedita Anno Dni 1712.

sygn. E16, Visitatio generalis archidiaconats Crusviciensis per ... Martinum Nicolaum Troynarski et Lucam Płachecki visitatores delegatos expedita, 1763-1764.

sygn. E 19, Acta visitationis generalis Rybinscianae archidiaconatus Crusviciensis 17791780 .

Archiwum Diecezjalne w Pelplinie

Zespół: Gedanensia - akta archidiakonatu pomorskiego

sygn. G1a [dublet sygn. G1b], Visitatio per totum Pomeraniae Archidiaconatum, qui rurales decanatus habet decem, ex voluntate Rmi ... Hieronymi Comitis a Rozdrazow, Dei gratia episcopi Vladislaviensis et Pomeraniae, per Sebastianum Liwierzki SRP capellanum ... facta. 1583-1598.

sygn. G2, Acta Consistorii Gedanensis 1592-1595.

sygn. G20b,Visitatio Archidiaconatus Pomeraniae sub felicissimis auspiciis (...) Bonaventurae de Niedzielsko Madaliński, Dei et Apostolicae Sedis gratia Episcopi Vladislaviensis et Pomeraniae a (...) Andrea Albinowski, Archidiacono Pomeraniae, Cantore Premisliensi, Praeposito Volboriensi Anno 1686 et 1687 peracta.

sygn. G24, Acta Visitationis (...) Christophori Antonii de Słupow Szembek I.U.D, archidiaconi Pomeraniae, officialis Gedanesis ac per Pomeraniam generalis Anno 1701 et 1702 expeditae.

sygn. G25, Visitatio PR. Christophori Antonii Szembek archidiaconi Pomeraniae 1702.

sygn. G26, Archidiaconatus Pomeraniae sub auspiciis (...) Constantini Feliciani de Szaniawy Szaniawski Episcopi Vladislaviensis et Pomeraniae per Joannem Casimirum Jugowski, Archidiaconum Pomeraniae visitatus A.D. 1710 et A.D. 1711.

sygn. G61, Visitatio generalis Ecclesiarum Archidiaconatus Pomeraniae tribus decanatibus Gedanensi, Starogardensi et Dirschaviensi dinstinctarum per PARD. Bartholomeum Franciscum Trochowski Ins. Collegiatae Crusv. canonicum, oficialem Svecensem praepositum Serocensem ab (...) Antonio Casimiro Ostrowski episcopo Vladisl. Et Pomeraniae delegatum commissarium et deputatum visitatorem generalem expedita, 1765-1766.

sygn. G62, Visitatio Ecclesiarum Decanatus Svecensis in Archidiaconatu Pomeraniae consistentium per ipsummet (...) Antonium Casimirum de Ostrow Ostrowski episcopum Vladisl. et Pomeraniae ... /et/ per (...) Lucam Płachecki canonicum Lublinensem, praepositum Iunivladislaviensem peracta et expedita A.D.1766.

sygn. 63a, Visitatio generalis decanatuum Pucensis et Leoburgensis, Mirachoviensis et Büttoviensis in dioecesis Pomerana consistentum sub felici regimine (...) Antoni Ca- 
simiri de Ostrow Ostrowski episcopi Vladisl. et Pomeraniae, officialatu vero (...) Cypriani Casimiri de Komorze Wolicki suffraganei Pomeraniae, vicarii in spiritualibus generalis ac parochi Gedanensis per me Bazilium Złocki Archidiaconi Pomeraniae (...) visitatorem generalem expedita A.D. 1766 .

sygn. G63b, Visitatio Generalis /Ostraviana/ decanatuum Pucensis et Leoburgensis, Mirachoviensis et Büttoviensis in Dioecesi Pomerana consistentium per me Basilium Złocki Archidiaconum Pomeraniae, praepositum Skarszeviensem, visitatorem generalem expedita A.D. 1766.

sygn. G69, Visitatio generalis Ecclesiarum decanatuum Buttoviensis, Leoburgensis et Mirachoviensis ex mandato (...) Josephi Rybiński episcopi loci-ordinarii Vladislaviensis et Pomeraniae per (...)/Joannem Josephum/ Gręca decanum praepositum Pucensem, praedictorem decanatuum ecclesiarum visitatorem generalem deputatum expedita anno 1780.

sygn. G70, Visitatio generalis ecclesiarum decanatuum Dirschaviensis et Starogardensis ex mandato (...) Josephi Rybiński episcopi Loci-ordinarii Vladisl. et Pomeraniae per PAR. Lucam Joannem Krzykowski canonicum Crusvic., notarium apostolicum, visitatorem delegatum peracta anno 1780 .

sygn. G71, Visitatio generalis ecclesiarum parochialium decanatuum Neoburgensis et Mevensis ex mandato (...) Josephi Rybiński episcopi Vladisl. et Pomeraniae per (...) Andream Schultz, canonicum Crusvic., decanum foraneum Dirschaviensem visitatorem generalem deputatum in anno 1780 et 1781 expedita.

sygn. G72, Visitatio generalis ecclesiarum parochialium in decanatu Gedanensi et Pucensi consistentium ex commissu (...) Josephi Rybiński episcopi Vladisl. et Pomeraniae per (...) Joannem Bastkowski canonicum cath. Livoniae, decanum foraneum et praepositum Starogardensem, generalem deputatum visitatorem ab a. 1782 inchoata et eodem anno expedita.

Zespół: Varia

sygn. V8, Echo sepulchralis sive Epitaphia, Inscriptiones studio et labore A.R.D. Joannis Borck Parochi Borzyszkoviensis et Breznensis collecta A.D. 1765, ADPelp., Pars I. sygn. V9, Echo sepulchralis sive Epitaphia, Inscriptiones ac Monumenta Varia Prussiae illiquae adjacentum Provinciarum (...) A.R.D. Joannis Borck Parochi Borzyszkoviensis et Breznensis collecta A.D. 1765, ADPelp., Pars II.

Archiwum Diecezjalne we Włocławku

Zespół: Akta biskupów kujawskich i pomorskich

sygn. W4 (98), [Wizytacje z czasów biskupa Rozrażewskiego z 1598 r.].

sygn. W5 (69), [Wizytacja archidiakonatu włocławskiego, kruszwickiego i pomorskiego z 1. 1582-1583].

sygn. W6 (70), [Wizytacja archidiakonatu kruszwickiego z 1594, 1597 i 1599].

sygn. 7 (71), [Wizytacta archidiakonatu pomorskiego z 1597 r.].

sygn. 13 (74), Visitatio ecclesiarum parochialium in archidiaconatu Vladislaviensis (iussu Matthiae Lubinski, episcopi Kujaviensi et Pomeraniae) per admodum reverendum dominum Sebastianum Grotkowski, I.U.D. Archidiaconum Vladislaviensem in anno Domini millesimosexcentesimotrigesimo nono et aliis, succesive facta expedita [1639-1647].

sygn. W14 (75), Visitatio ecclesiarum parochialium in archidaconatu Vladislaviensi, sub felici regimine (...) Constantini Feliciani Szaniawski, Dei et Apostolicae Sedis gratia episcopi Vladislaviens[si] et Pomeraniae, per (...) Joannem Stanislaum Borzysławski, archidaconum Vladislaviensem in anno Dni millesimo sepingentesimo undecimo expedita. 
sygn. W15 (76), Synopsis ecclesiarum et status earum parochorum tum et decretorum reformationis ex praesenti visitatione archidaconatus Wladislaviensis connotata anno $\mathrm{D}$ [omini] 1711.

sygn. W25 (83), Visitatio ecclesiarum decanatuum Covaliensis et Izbicensis, per me Matthaeum Błędowski decanum Vladislaviensem, visitatorem generalem, ab (...) Antonio Ostrowski episcopo Vladislaviensi et Pomeraniae datum et deputatum, anno Domini 1765-to expedita (1765-1766).

sygn. W26 (84), Visitatio trium in diaecesi Vladislaviensi decanatuum Nieschoviensis, Służevensis, Bobrovicensis, ex commisso (...) Antonii Casimiri in Ostrow Ostrowski Dei et Apostolicae Sedis gratia episcopi Vladislaviensis et Pomeraniae, per (...) Franciscum Ksavierium a Witoszyn et Grochowalsk Grochowalski U.I.D [...] anno Domini 1766-to expeditae.

sygn. W27 (85), Visitatio generalis decanatuum Brestensis, Radziejoviensis et Iunivladislaviensis sub felici regimine (...) Antoni Casimiri de Ostrow Ostrowski Dei et Apostolicae Sedis gratia episcopi Vladislaviensis et Pomeraniae, per me Ludovicum Carolum Bratoszewski ecclesiae cathedralis Vladislaviensis primicerium facta anno Domini 1766-to.

Visitatio decanalis Służeviensis, ex mandato (...) loci ordinarii (Josephi Rybiński), iuxta puncta pro dioecesis Vladislaviensis et Pomeraniae [...] per (...) Michaelem Maiewski decanum Służevensem, parochum Sinniarzeviensem expedita (1778), sygn. W36.

sygn. W37, Visitatio generalis decanatus Bobrovnicensis, sub felici regimine (...) Josephi Rybiński episcopi Vladislaviensis et Pomeraniae, per (...) Matthiam Nałęcz decanum cathedralem Vladislaviensem anno Domino 1779 expedita.

sygn. W38, [Wizytacja dekanatów brzeskiego i radziejowskiego, przeprowadzona w $1779 \mathrm{r}$. za rządów bpa Józefa Rybińskiego].

sygn. W39 (89), Visitatio generalis ecsiarum decanatum Brestensis et Radziejoviensis, ab (...) Josepho Rybiński episcopoo Vladislaviensi et Pomeraniae [...] per (...) Josephum Gliński $[\ldots]$ ad eandem perficiendam specialiter delegatum, expedita anno Domini 1779.

sygn. W40 (88), Visitatio generalis essiarum decanatuum Kovaliensis et Izbicensis in dioecesi Vladislaviensi, ex mandato (...) Josephi Rybiński episcopi loci ordinarii Vladislaviensis et Pomeraniae, per (...) Casimirum Lipski archidiaconum cathedralem vladislaviensem, abbatem commendatarium Lubinensem, a mense novembri anno 1779 ad 10 februari anno 1781 peracta.

sygn. W41 (89), Visitatio generalis essiarum decanatuum Służeviensis et Nieschoviensis, ex mandato (...) Josephi Rybiński episcopi Vladislaviensis et Pomeraniae, per (...) Basileum Złocki archidiaconum Pomeraniae in ecclesia cathedrali Vladislaviensi visitatorem generalem deputatum reassumpta anno 1779-no.

sygn. W42 (354), Visitatio generalis decanatus Volboriensis, authoritate et speciali commissione (...) Josephi Rybiński Dei et Apostolicae sedis gratia episcopi Vladislaviensis et Pomeraniae [...] per (...) Adalbertum Leszczyc Skarszewski canonicum cathedralem Vladislaviesem et Camenecensem [...] expedita anno 1779.

sygn. W43 (90), Visitatio Generalis Ecclesiarum Decanatuum Svecensis et Fordonensis $1780-1781$.

sygn. W46, Decreta reformationis pro ecclesiis et beneficiis decanatus Nieschoviensis (1779-1782).

sygn W47, Principaliora puncta decretorum reformationis pro singulis ecclesiis decanatus Radziejoviensis, in visitatione generali anno Domini 1779 expedita latorum (17791782). 
sygn. W48, Decreta reformationis pro ecclesiis et beneficiis decanatus Służeviensis (17791782).

\section{Źródla drukowane}

Ad historiam ecclesiasticam Pomeraniae apparatus pauper subsidia literaria poscens a viris bonis et doctis cellectus ad interim a Georgio Schwengel Carthusiae priore 1749, curavit Bruno Czapla, „Fontes Towarzystwa Naukowego w Toruniu”, 16/19 (1912-1915).

Das Totenbuch des Prämonstratenserinnen-Kloster Zuckau bei Danzig, hrsg. von M.Perlbach, w: Quellen und Darstellungen zur Geschichte Westpreussens, Danzig 1906, s. $189-222$.

Decretales Summorum Pontificum pro Regno Poloniae et Constitutiones Synodorum Provincialium et Dioecesanarum Regni eiusdem ad summam collectae, ed. Z.Chodyński, E.Likowski, t.1-3, Posnaniae 1883-1885

Die Matrikel des päpstlichen Seminars zu Braunsberg 1578-1798. Im Namen des Historischen Vereins für Ermland herausgegeben und mit biographischen Zusätzen versehen von Prof. Dr. Georg Lühr, Braunsberg 1925.

Liber mortuorum monasterii Coronoviensis O.Cist., wyd. A. Mańkowski, „Fontes Towarzystwa Naukowego w Toruniu". 25(1931).

Die Schüller des Braunsberger Gymnasiums von 1694 bis 1776, w: Monumenta Historiae Warmiensis, Lieferung 36-38, Bd. XII, hrsg. G. Lühr, Braunsberg 1932-1934.

Die Schüler des Rösseler Gymnasium nach dem Album der Marianischen Kongregation, von G.Lühr, ,Zeitschrift für die Geschichte und Altertumskunde Ermlande”, 15 (1905) s. 391-464, 579-704; 16 (1910) s. 158-312; 17 (1910) s. 1-144; 18 (1913) s. 138-167.

Statuta synodalia Dioecesis Wladislaviensis et Pomeraniae, collegit et edidit Zeno Chodyński, Varsaviae 1890.

\section{Opracowania}

Chodyński Stanisław, Biskupi sufragani włocławscy, Włocławek 1906.

Chodyński Stanisław, Konsystorze w diecezji kujawsko-pomorskiej, Włocławek 1914.

Gręźlikowski Janusz, Recepcja reformy trydenckiej $w$ diecezji włocławskiej $w$ świetle ustawodawstwa synodalnego, Włocławek 2000.

Jabłońska Anna, Funkcje społeczne parafii archidiakonatu gnieźnieńskiego w XVII wieku, Kielce 2013.

Karłowski Kazimierz, Z dziejów zarządu majątku kościelnego, „Miesięcznik Kościelny. Organ Archidiecezji Gnieźnieńskiej i Poznańskiej”, 51 (1936) s. 209-212, 254-257.

Kloskowski Grzegorz, Sylwetki cystersów pelplińskich w nekrologach i kronice, „Studia Pelplińskie", 44 (2011) s. 151-302

Kopiczko Andrzej, Duchowieństwo katolickie diecezji warmińskiej l. 1525-1821, cz. 1, Olsztyn 2000.

Kracik Jan, Potrydencki system rekrutacji duchowieństwa $w$ diecezji krakowskiej XVI-XVIII wieku, „Analecta Cracoviensia” 10 (1978) s. 471-493.

Kracik Jan, Vix venerabiles. $Z$ dziejów społecznych niższego kleru parafialnego $w$ archidiakonacie krakowskim w XVII-XVIII w., Kraków 1982.

Librowski Stanisław, Wizytacje diecezji kujawskiej, cz. 1: wizytacje diecezji kujawskiej i pomorskiej, t. 1: Opracowanie archiwalno-źródtoznawcze, z. 1: Wstęp ogólny, „Archiwa, Biblioteki i Muzea Kościelne" 8 (1964), s. 5-186,

Librowski Stanisław, Wizytacje diecezji włocławskiej, cz. 1: wizytacje diecezji kujawskiej 
i pomorskiej, t. 1: Opracowanie archiwalno-źródłoznawcze, z. 2: Wizytacje w latach 1123-1421, „Archiwa, Biblioteki i Muzea Kościelne”, 10 (1965) s. 35-206.

Librowski Stanisław, Katalog rubrycel i schematyzmów diecezji i zakonów historycznej Polski znajdujacych się $w$ księgozbiorze podręcznym Archiwum Diecezjalnego we Włocławku, cz. 1 Rubrycele i schematyzmy diecezjalne, „Archiwa, Biblioteki i Muzea Kościelne", 25 (1972) s. 39-113.

Litak Stanisław, Atlas Kościoła łacińskiego w Rzeczypospolitej Obojga Narodów w XVIII w., Lublin 2006.

Litak Stanisław, Kościół łaciński w Rzeczypospolitej około 1772 r., Lublin 1996.

Litak Stanisław, Parafie w okresie od końca XVI do XVIII w., w: Ksiegga Tysiaclecia katolicyzmu w Polsce, red. M. Rechowicz, Lublin 1969, s. 99-110.

Litak Stanisław, Parafie w Rzeczypospolitej XVI-XVIII w., Lublin 2004.

Litak Stanisław, Struktura i funkcje parafii w Polsce, w: Kościót w Polsce, t. 2, red. J. Kłoczowski, Kraków 1969, s. 261-481.

Litak Stanisław, Zagadnienie parafii w XVI-XVIII w., „Znak”, 27 (1965) s. 1528-1562.

Nowicki Tomasz, Carbona ecclesiae - przyczynek do badań nad dochodowościa kościołów parafialnych $w$ archidiakonacie pomorskim na przykładzie wizytacji biskupa Rybińskiego z 1780-1781 roku, „Studia Pelplińskie”, 42 (2010) s. 249-259.

Nowicki Tomasz, Die territoriale Herkunft der katholischen Geistlichkeit im Archidiakonat Pommerellen im 18. Jahrhundert, ,Zeitschrift für Ostmitteleuropa-Forschung”, 49 (2000) Hf. 1, s. 19-37.

Nowicki Tomasz, Dos ecclesiae and dos parochii illustrated with an example of the canonical visitation of the parishes in the diocese of Włoctawek in the years 1710-1711, „Archiwa, Biblioteki i Muzea Kościelne”, 106 (2016) s. 101-112.

Nowicki Tomasz, Ministri ecclesiae. Stużba kościelna $i$ witrycy $w$ diecezji włocławskiej w XVIII w., Lublin 2011.

Nowicki Tomasz, Plebani archidiakonatu pomorskiego w XVIII w., Lublin 2008.

Nowicki Tomasz, Słownik biograficzny rządców parafii archidiakonatu pomorskiego w osiemnastym wieku, Lublin 2004.

Nowicki Tomasz, Terminy święceń na przykładzie księgi czynności pontyfikalnych biskupa Wojciecha Bardzińskiego z lat 1709-1723, w: Kapłan, historyk, pedagog. Ksiega pamiatkowa ks. infulata dra Stanistawa Grada z okazji 70-lecia urodzin i 35-lecia pracy dydaktycznej w Wyższym Seminarium Duchownym $w$ Łodzi, red. M. Różański, Łódź 2013, s. 267-278.

Nowicki Tomasz, Terminy udzielania święceń kapłańskich $w$ XVIII wieku na przykładzie księgi święceń biskupa Franciszka Kanigowskiego, w: Archiva temporum testes, Źródła historyczne jako podstawa pracy badacza dziejów. Księga pamiatkowa ofiarowana Profesorowi Stanisławowi Olczakowi, red. G. Bujak, T. Nowicki, P. Siwicki, Lublin, 2008, s.-384-393.

Nowicki Tomasz, Uposażenie kleru parafialnego $w$ archidiakonacie pomorskim $w$ XVIII wieku, „Roczniki Humanistyczne”, 51 (2003) z. 2, s. 45-99.

Nowicki Tomasz, Źródła do badań biograficznych nad osiemnastowiecznym katolickim duchowieństwem parafialnym, „Studia Archiwalne”, 1 (2004) s. 101-107.

Olczak Stanisław, Zarzadcy parafii diecezji poznańskiej w pierwszej połowie XVII w. (w świetle wizytacji kanonicznych), „Roczniki Humanistyczne”, 30 (1982) z. 2, s. 43-79.

Olczak Stanisław, Duchowieństwo parafialne diecezji poznańskiej w końcu XVI $i$ w pierwszej połowie XVII w., Lublin 1990.

Olczak Stanisław, Jezuici otrzymujący święcenia z rąk biskupów poznańskich na przełomie XVI/XVII wieku, „Roczniki Humanistyczne”, 31 (1983) z. 2, s. 85-104. 
Olczak Stanisław, Kościoły parafialne $w$ archidiakonacie włocławskim XVI-XVIII w., Lublin 2004.

Olczak Stanisław, Poznańskie księgi święceń jako źródło do badań nad cystersami, w: Historia i kultura cystersów $w$ dawnej Polsce $i$ ich europejskie związki, Poznań 1987, s. 489-498.

Różański Mieczysław, Duchowieństwo parafialne archidiakonatu uniejowskiego w XVIII w. Studium prozopograficzne, Łódź 2010.

Rybczyński Henryk, Duchowieństwo, stan duchowny, w: Encyklopedia katolicka, t. 4, red. R. Łukaszyk, Lublin 1983, kol. 307-309.

Rybczyński Henryk, Duchowny, w: Encyklopedia katolicka, t. 4, Lublin 1983, red. R. Łukaszyk, kol. 309-311.

Sołtyszewski Stefan, Dochody kościelne pod zarządem witrykusów w polskim ustawodawstwie synodalnym, „Prawo Kanoniczne”, 3 (1960) nr 3-4, s. 312-333.

Sołtyszewski Stefan, Zarzą majątkiem kościelnym w kanonicznym ustawodawstwie powszechnym, „Prawo Kanoniczne”, 3 (1960) nr 3-4, s. 335-346.

Stanke Marianne, Katholische Kirchenbücher in Ost- und Westpreussen (Stand 1999), Bonn 2000.

Szady Bogumił, Wizytacje diecezji chetmskiej w XVII wieku, „Archiwa, Biblioteki i Muzea Kościelne", 82 (2004) s. 269-288.

Szczepaniak Jan, Duchowieństwo diecezji krakowskiej w XVIII w. Studium prozopograficzne, Kraków 2010.

Walachowicz Tadeusz, Kumulacja beneficjów, w: Encyklopedia katolicka, t. 10, red. E. Ziemann, Lublin 2004, kol. 224.

Wiśniewski Jan, Fabrica ecclesiae na terenie oficjalatu pomezańskiego $w$ świetle wizytacji biskupów XVII-XVIII w., cz. 1, „Archiwista Polski”, 12 (2007) nr 2, s. 47-56. 


\section{SOURCES FOR PROSOPOGRAPHIC RESEARCH ON THE CLERGY AND THEIR AUXILIARY PERSONNEL IN THE PARISHES OF THE DIOCESE OF WLOCLAWEK IN THE EARLY MODERN PERIOD}

\section{Summary}

The sources regarding modern parishes record groups of people managing and supporting these centres. These were ministrii ecclesiae, that is priests and their auxiliary personnel. The priests - ministri sacramentorum - played the most important role in a parish; their work, however, extended beyond religious and pastoral duties. As far as laypeople are concerned, they assisted priests in parish work. They were sacristans, teachers, cantors, organists, organ pumpers, bell-ringers, gravediggers, midwives and altar servers.

The article presents the sources providing information on the groups mentioned above. The archival material that is analysed concerns the diocese of Włocławek in the pre-partition period. The most important and significant sources are the records of canonical visits, containing a great amount of information about the people involved in parish life. These records are not entirely consistent: they do not always include all parishes of the diocese, and above all, they differ in the scope of information, as they were produced on the basis of various questionnaires. Nevertheless, the ones containing a great number of details are invaluable sources for research on the parish clergy and their auxiliary personnel.

Other sources useful for research on the parish clergy are the records produced by consistory and episcopal offices. In the latter case, these are the books of episcopal pontifical duties, which, especially the ones of holy orders, are particularly significant for research purposes. In addition, register books constitute an exceptional source of information (although rather of an auxiliary nature) for prosopographical research on the clergy and the people who helped them. Parish offices created registers systematically from the Council of Trent onwards. Consequently, the continuity of the documentation enables a comprehensive description of the subject under study.

In addition, one can learn a lot about the clergy and parish auxiliary personnel from other types of sources: the records of colleges and theological seminaries, monastic books of the deceased, the description of churches and parishes provided by various authors, chapter records, diocesan schematisms (appearing at the end of the eigthteenth century), and secular records such as books from municipal offices.

Key words: prosopography; the clergy; auxiliary personnel; the diocese of Włocławek 